\title{
Ebelik Mesleğinde Duygusal Emek ${ }^{1}$
}

\author{
Dilek HACIVELioĞLU ${ }^{2}$ - Doç. Dr. Hafize ÖZTÜRK CAN³ - Doç. Dr. Nazan TUNA ORAN ${ }^{4}$
}

Başvuru Tarihi: 23.01.2020 Kabul Tarihi: $30.11 .2020 \quad$ Makale Türü: Derleme

\section{Öz}

Çalışanların hizmet verdikleri kişide duygu yaratma çabası olarak tanımlanan duygusal emek, sağlık alanında daima tartışma konusu olan bir kavramdır. Sağlk çalışanları hizmet ve bakım sürecinde etkili sonuca ulaşmak için duygusal emek sergilemek durumundadır. Ebelik mesleği de duygusal emek gerektiren bir meslektir. Gebelik ve doğum olayı sürece dâhil olan herkes için duygusal açıdan olumlu ya da olumsuz çok fazla deneyim barındırır. Bu duygularla başa çıkmada ve ailelere destek sağlamada ebeler kilit rol oynamaktadır. Anne ve çocuk sağhl̆g açısından önemli bir konumda olan ebelik mesleğinin duygusal yönlerinin incelenmesi önem taşımaktadır. Bu derleme, ebelik mesleğinde duygusal emeği literatür bilgileri eşliğinde incelemek ve literatüre katkı să̆lamak amacıyla yazılmıştır.

Anahtar Kelimeler: Duygusal Emek, Ebelik, Ebelik Duygusu, Kuram

Atıf: Hacıvelioğlu, D., Öztürk Can, H. ve Tuna Oran, N. (2020). Ebelik mesleğinde duygusal emek. Anadolu Üniversitesi Sosyal Bilimler Dergisi, 20(4), 163-172.

\footnotetext{
${ }^{1}$ Çalıșma etik kurul izni gerektirmemektedir.

${ }^{2}$ Celal Bayar Üniversitesi Sağlık Bilimleri Enstitüsü Ebelik Ana Bilim Dalı Doktora Öğrencisi, dyakti@gmail.com, ORCID: 0000-0003-4806-6888

${ }^{3}$ Ege Üniversitesi Sağllk Bilimleri Fakültesi Ebelik Bölümü, hafizeztrk@gmail.com; hafize.ozturk@ege.edu.tr, ORCID: 0000-0001-8213-3330

${ }^{4}$ Ege Üniversitesi Sağlık Bilimleri Fakültesi, Ebelik Bölümü, nazan.oran@ege.edu.tr, ORCID: 0000-0003-2103-6769
} 


\title{
Emotional Labor in the Midwifery Profession
}

\author{
Dilek HACIVELioĞLU - Assoc.Prof. Dr. Hafize ÖZTÜRK CAN - Assoc. Prof. Dr. Nazan TUNA ORAN
}

\begin{abstract}
Emotional labor, which is defined as an effort to create emotions in employees, is always a subject of controversy in the field of health. Health care workers have to exert emotional labor in order to reach an effective result in the service and care process. Midwifery is a profession that requires emotional labor. Pregnancy and childbirth have a lot of emotional positive or negative experiences for everyone involved. Midwives play a key role in coping with these feelings and providing support to families. It is important to examine the emotional aspects of midwifery profession which is important for mother and child health. This review was written to examine emotional labor in the midwifery profession along with literature information and to contribute to the literature.
\end{abstract}

Keywords: Emotional Labor, Midwifery, Emotion of Midwifery, Theory 


\section{Giriş}

İnsanı diğer canlılardan ayıran en önemli özelliklerden biri duygularıdır. Son yıllarda duyguların özellikle hizmet sektöründe yer alması gerekliliği, “duygusal emek” kavramını öne çıkarmıştır. Bu kavram, literatüre 1983 yılında Arlie Hochschild tarafından kazandırılmıştır. Diplomat bir ailede büyüyen Hochschild'in, çocukluğunda bulunduğu ortamlarda yaşanan gülümseme zorunluluğu, uzun süreli el sıkışma gibi anlamlandıramadığı davranışların nedenini merak etmesi bu konuya ilgi duymasına neden olmuştur (Özen, 2017). Hochschild'e göre insanlar sosyal yapının belirlediği kurallara göre duygularını ve davranışlarını sergilemekte, bu kurallar ise mesleklere ve durumlara göre değişmektedir (Güngör, 2009, s. 170).

Duygusal emek kavramı "çalışanların hizmet verdikleri kişilerle yaşadıkları etkileşimde, kurum ya da işverenin isteği doğrultusunda kendilerinden beklenen duyguları sergilemesi durumu” olarak tanımlanır (Güngör, 2009). Bu süreçte çalışanlar, belirli bir duygu ifadesi takınırlar ve duygusal gösterimlerini düzenleme çabası içine girerler (Yılmaz, 2016). Bu durumda, 'gülmemeye çalışma' ya da gülümsemeye zorlanma', 'ağlamamaya zorlama' gibi duygulara aktif olarak yapılan bir müdahale söz konusudur (Bolton ve Boyd, 2003). Kurumun/işverenin beklentilerini karşılamak amacıyla duygusal emek davranışlarının sergilenmesinin bazı olumlu/olumsuz etkileri bulunmaktadır. Duygusal emek, iş dünyasında rekabet gücünde fark oluşturma, kurumsal olarak tercih edilme, iş veriminde ve kalitesinde artma, hizmet alanlarda memnuniyet yaratma gibi olumlu etkilerinin yanında; çalışanlarda tükenmişlik, iş memnuniyetsizliği, otonomi kaybı, ruhsal ve fiziksel sorunlar gibi sonuçlara da yol açabilmektedir (Oral ve Köse, 2011, s. 465). Birçok çalışan kurumun/işverenin beklentileri karşılamak istese de bazen gerçekten hissedilen duygular beklenen duygularla uyuşmamakta dolayısıyla "duygusal uyumsuzluk" ortaya çıkmaktadır (Mann, 2005, s. 304).

Hizmet alan bireylerle yüz yüze ya da sözlü iletişim kurulması, onların duygularını etkileme gerekliliğinin olması ve işverenlerin çalışan kişilerin duygularını kontrol ederek düzenlemesi v.b durumlar duygusal emek sergilenmesine ihtiyaç duyulan mesleklerin ortak özellikleridir (Çaldağ, 2010, s. 7). Çalışanlar duygusal emek sarf ederken, yüzeysel ve derinlemesine olmak üzere iki davranış mekanizması kullanmaktadır. Beklentilere yönelik olarak gerçekte hissedilmediği halde gösterilen, duyguların ve davranışların uyumsuz olduğu durumda yüzeysel davranış şekli söz konusudur. Bireyin kendinden beklenen duyguyu gerçekten hissedebilmek için çaba göstermesi ise derinlemesine davranıştır. Bu mekanizmaların her ikisi de çalışan kişi için güç olabilmekte, stres ve tükenmişlik oluşturabilmektedir (Tunç vd., 2014).

Bir hizmet sektörü olarak sağlıkla ilgili çalışma alanları duygusal emeğin en fazla yer aldığı alanlar olup, tartışılan bir konu olarak yerini almıştır. Duygusal emek sağlık çalışanlarının rollerinin bir parçasıdır. Çünkü kişilerin duygular ile yüzleşerek etkili sonuca gitmelerini sağlayan duygu yönetimi, sağlık hizmeti verenler ve bu hizmeti alanlar için çok önemlidir (Mann, 2005; Değirmenci Öz ve Baykal, 2018). Zira fiziksel, zihinsel veya duygusal, sağlık hizmeti almaya gereksinimi olan kişiler, sağlı̆̆ın yükseltilmesi, korunması ve hastalık ortaya çıktığında tedavi ve bakıma yönelik hizmet beklerken aynı zamanda desteklenmeye, cesaretlendirilmeye, güdülenmeye, ilgi gösterilmeye de ihtiyaç duymaktadır (Atilla Gök, 2015).

Sağlık alanında duygusal emek ile ilgili yapılan araştırmaların yetersizliği, araştırmaları yönlendirecek teorik model eksikliği ve var olan çalışmaların sınırlı olması duygusal emek ile ilgili yeni çalışmalara yönelmek ve farkındalık yaratılması gereksinimini ortaya koymaktadır (Mann, 2005, s. 305). Sağlık hizmetlerinde duygusal emek çalışmaları genel olarak hemşirelik ile ilgili olsa da diğer sağlık mesleklerini de içeren çalışmalar mevcuttur (Smith ve Kleinman, 1989; Çaldağ, 2010; Uzuntarla, 2015; Delgado vd., 2017; Edward vd., 2017; Kılınç, 2018; Özbay, 2019; Yetim ve Erigüç, 2019). Ancak duygusal emeğe yönelik yapılan hemşirelik araştırmalarının daha çok hastalık ortamlarına odaklanması, konunun ebeliğe ilişkilendirilmesinde sınırlılık yaratmıştır (Hunter, 2001, s. 439). Oysaki ebeler genellikle sağlıklı kadınların ve bebeklerin bakımı ile ilgili hizmet vermektedir. Ebelik mesleğinde duygusal emeğe etki eden faktörleri ve belirlenen duygusal emek sergileme alanlarını bilmek, hizmet alanlar ve kurum açısından olumlu sonuçlar sağlayabilir. Ayrıca ebelik ile 
ilgili tanımlanmamış duygusal emek alanlarının açığa çıkması mümkün olabilir. Bu bağlamda mevcut çalışma, ebelik mesleğinde duygusal emeği literatür bilgileri eşliğinde incelemek ve literatüre katkı sağlamak amacıyla yazılmıştır.

\section{Ebelik Mesleğinde Duygular}

Gebelik ve doğum olayı, kadın ve ailesi başta olmak üzere sürece dâhil olan herkes için duygusal açıdan olumlu ya da olumsuz çok fazla deneyimi barındırmakta, ebe (midwife=kadın ile) ise bu duyguların yönetilmesinde ve destek sağlamada kilit rol oynamaktadır (Hunter, 2001). Ebelerin duyguları yönetme şekilleri kendileri ve hizmet verdikleri kadınları etkileyeceğinden, hem kendi duygularını anlamak hem de karşı tarafın duygusal yönlerini ve tepkilerini doğru anlamlandırmak son derece önemlidir (Hunter, 2004). Kadınlar, kendi yaşam evrelerinde (gebelik öncesi, gebelik süreci, doğum, doğum sonu dönemi) bir ebe ile ilişki halinde olmay1 önemserler. Bu önemliliğin derecesi kadınlara göre değişmekte ve farklı alanlarda olabilmektedir. Ebeler, yaşam döngüsündeki gelişimsel olaylar, kişiler arası iletişim, doğum deneyimleri, klinik beceri ve bilgi, bireysel bakım, güvenlik hissi gibi pek çok noktada kadının hayatına dokunabilmekte, karşlıklı ve samimiyet bağlamında kadın tarafından arkadaş olarak görülmektedir (Hunter, 2006).

Literatürde ebelik mesleğinde açıkça duygulara odaklanan ilk kişinin Billie Hunter olduğu görülmektedir. Hunter, ebelerin işleri ve kadınlarla ilişkileri ile ilgili algılarına yönelik kanıtların yetersiz olduğunu, çalışmaların genellikle stres ve tükenmişlik konularına odaklandığını belirtmiştir (Hunter, 2001; Hunter, 2017). Ebelik mesleğinde hissedilen duygu ve bu duygularla nasıl baş edilebileceği Hunter'ın temel sorusu olmuş ve duygusal emeğin sosyolojik teorilerini incelemiştir (Hunter, 2017). Ebe ve kadın arasındaki ilişkinin, kadınların doğum deneyimi kalitesi üzerinde önemli etkileri olduğuna dair göstergeler olmasına rağmen ebelerin bu ilişkilerdeki duygusal deneyimleri ile ilgili yeterince kanıt olmaması ebelikte duygu kaynaklarını tanımlamaya itmiştir. Hunter, işyerinde duygusal emeğe ilişkin literatürü gözden geçirmek ve ebelik çalışmasında var olan duygu kaynaklarını tanımlamak amacıyla yaptığı meta analizi çalışmasında (2004), ebelik mesleğinin yüksek düzeyde duygusal çalışma yaratma potansiyeline sahip olduğunu ve ebelikte duygularla ilgili keşfedilmesi gereken çok daha fazla şey olduğunu belirtmiştir. Ebelerin iş hayatlarını iyileştirmek ve hem kadınların hem de ailelerin ihtiyaçlarını karşılamak için işteki duygu anlayışlarını geliştirmelerinin önemli olduğu; ebelik eğitim ve uygulamalarında bilgi birikimini geliştirmek için bu alanda daha fazla araştırmaya ihtiyaç olduğu sonucuna varmıştır (Hunter, 2001).

Ebelerin duygularıyla ilgili yapılan çalışmalar, ebe ve kadınlar arasındaki ilişkileri anlamaya katkıda bulunmaktadır (Hunter 2006). Ebeler mesleki profesyonellikleri gereğince tarafsızlıklarını korumak için kadınlarla empati kurma mücadelesinde duygusal emek sergilemektedirler (Kirkham, 2018, s. 110-111). Bu süreçte 'duygusal tarafsızlık' ve 'duygusal farkındalık' durumları da söz konusu olmaktadır. Daha çok hastanede çalışanlarda tanımlanan duygusal tarafsızlık, ebelerin profesyonel kimliklerini sürdürmek için duygularını bastırmalarıyla oluşur. Genellikle sahada çalışanların uyum sağladığı duygusal farkındalık ise paylaşım ve destek sayesinde ebelerin duygularını yönetmesiyle ortaya çıkmaktadır (Hunter, 2017, s. 192).

Hunter kuramını geliştirme sürecinde ebelikte duygu araştırmaları için yaptığı çalışmalarda (Hunter, 2004; Hunter, 2005; Hunter, 2006) etnografik yaklaşım benimseyerek farklı bakış açılarına ulaşmak ve ebelerin kendi hikâyelerinden sonuçlara ulaşmak için nitel çalışma yöntemi kullanmıştır. Araştırmalara katılan ebelere göre 'kadın ile' ve 'kurum ile' kavramlarının çelişmesiyle gelişen gerilim ve uyumsuzluğun yönetilmesi duygusal emeği ortaya çıkarmıştır. Hunter, 'kadın ile' kavramını; kadınlar ile çalışıp onların bireysel ihtiyaçları ile ilgilenmek ve doğumu normal yaklaşım olarak desteklemek şeklinde tanımlamaktadır. 'Kurum ile' kavramı ise görev tamamlamaya odaklı, birçok kadın ve bebeğin bakımının sağlandığı yoğun iş koşullarının olduğu doğum servislerinin gereksinimlerine yönelik yaklaşımdır (Hunter, 2017, s. 191-192). 
Hunter farklı alanlarda çalışan ebelerle yaptı̆̆ 1 çalışmalarında;

Hunter (2004)'ın yaptığı nitel araştırmada, çalışma yeri ve süresi bakımından ebelerin çalıştıkları kuruma göre farklı değer ve bakış açıları sergilediklerini gözlemlemiştir. Bu çalışmada toplum temelli çalışan ebeler ve hastane ebelerinin değerler ve bakış açıları açısından farklı oldukları, hastane ebelerinin tıbbi bakım yaklaşımıyla hizmet ihtiyacını karşılayan, zorunlu olarak 'kurum ile' ideolojisini benimseyen grup olduğu; toplum temelli çalışan ebelerin ise doğal doğum modelini destekleyebilen, kişiselleştirilmiş yaklaşımı benimseyen 'kadın ile' ideolojisinde oldukları bulunmuştur.

Hastane merkezli ebe duygularını tanımlamak amacıyla hastanede çalışan ebelerle yaptığı çalışmada (Hunter, 2005); hastanede çalışan ebelerde meslektaş ilişkilerinden kaynaklı önemli sorunlar yaşandığ belirtilmektedir. $\mathrm{Bu}$ çalışmada, kıdemli ebelerin zorbalık davranışları sergilediği, daha genç ebelerin kendilerini genellikle "kadın ile" ideolojisi ile müdahaleci olmayan bir yaklaşımın savunucuları olarak konumlandırdığı, üst düzey pozisyondaki kıdemli ebelerin ise daha çok 'kurum ile' ideolojisi ile yaklaştıkları belirlenmiştir.

Toplum temelli çalışan ebelerle yaptığ diğer araştırmasında (2006), bir ebe-kadın ilişkisi modeli geliştirmiştir. Model dört temel durumdan oluşmaktadır: Dengeli değişim, reddedilen değişim, ters çevrilmiş değişim ve sürdürülemez değişim. Kadınların bakımı için kişiselleştirilmiş bir yaklaşım benimsendiğinde ve onların ebelerin tavsiyelerine karşı duyarlı olduklarında karşılıklı 'verme ve alma' durumunun oluştuğunu ve dengeli değişimin söz konusu olduğunu vurgulamıştır. Ebeler ve anneler arasındaki etkileşimlerin, kadının ebeyi reddetmesinden ebeye aşırı bağımlı bir şekilde gerçekçi olmayan beklentilerle yaklaşmasına kadar çok geniş ölçüde değişebildiğini ve duygusal olarak zor durumların ortaya çıkabildiğini belirtmektedir. Çalışmada ebeanne etkileşimleri değişiminde çevresel faktörler, iş yükü, zaman baskısı gibi durumların ve kadın ile ebe arasında beklenen ilişkileri bir şekilde kesintiye uğratan farklı etmenlerin rol oynadığ 1 ileri sürülmektedir (Hunter, 2006).

Hunter, ebeliğin duygusal alanını haritalamak amacıyla 2010 yılında tekrar bir gözden geçirme çalışması yapmıştır. Bu literatür taramasında dört ana tema belirlemiştir:

- Koşulların ve annelik bakımı organizasyonunun etkisi,

- Ebe-kadın ilişkilerinde duygu çalışması,

- Meslektaş ilişkilerinde duygu çalışması,

- Duygu çalışması zorlama mı hediye mi?

$\mathrm{Bu}$ temaların birbirinden ayrı düşünülemeyeceği, hepsinin iç içe geçmiş durumda olduğu belirtilmektedir. Ebelikte duygu çalışmalarının odak noktasında hizmet sunumu, iş yeri ölçütlerinin ve bakım modellerinin duygu yönetiminde önemli etkisi olduğu belirtilmiştir. Büyük hastanelerde benimsenen batılılaşmış doğum bakımında, kurumsal beklentilerin sağlanması için duyguların bastırılması ve kurum odaklı çalışılmasının hem kadınlara hem de ebelere zarar verdiği belirtilmiştir. Teknik işlerin fazlalığı, işgücü sıkıntısı, kadınlara yardım ve bakım için zaman kalmaması mesleğin profesyonel idealleriyle çelişmiştir (Hunter, 2010).

Hunter'ın yaptığı çalışmaların bulgularından oluşan, çalışma şartları, mesleki kimlik, mesleki ideoloji ile duygu yönetimi arasındaki bağlantılarla tanımladığı teorik çatı Tablo 1'de görülmektedir. 
Tablo 1

Ebelik Uygulamalarında Çalışma Şartları, Mesleki Kimlik, Mesleki İdeoloji ve Duygusal Emek

\begin{tabular}{|c|c|c|c|}
\hline Şartlar & Mesleki kimliğin yönleri & $\begin{array}{l}\text { Mesleki } \\
\text { ideoloji }\end{array}$ & Duygusal emek \\
\hline $\begin{array}{l}\text { Hastane-tabanlı } \\
\text { uygulama }\end{array}$ & $\begin{array}{l}\text {-Tibbi yaklaşım } \\
\text {-Adil bakımın temini } \\
\text {-Otonominin azalması } \\
\text {-Birbirinin yerine geçen } \\
\text { ebeler } \\
\text {-Müşteriler ile ilişkinin } \\
\text { öneminin azalması } \\
\text {-Kuruma ve meslektaşlara } \\
\text { karşı bağlılık duygusunun } \\
\text { artması (Kurum odaklı } \\
\text { çalışma eğiliminin } \\
\text { artması) }\end{array}$ & $\begin{array}{l}\text { 'Kurum } \\
\text { ile' }\end{array}$ & $\begin{array}{l}\text { 'Kadının yanında olmak'/'kadın ile birlikte } \\
\text { olmak'(kadın ile) ideali ile 'kurumun } \\
\text { taleplerini karşılama'/'iş odaklı çalışma' } \\
\text { (kurum ile) zorunluluğu arasındaki } \\
\text { dengesizliği gidermek için. 'Duygusal } \\
\text { tarafsızlık'ın egemenliği. }\end{array}$ \\
\hline $\begin{array}{l}\text { Entegre saha ve } \\
\text { hastane uygulaması }\end{array}$ & Mesleki kimlik=belirsiz & $\begin{array}{l}\text { 'Birbirine } \\
\text { zit } \\
\text { düşünce } \\
\text { tarzı' }\end{array}$ & Artan duygusal emek \\
\hline $\begin{array}{l}\text { Toplum tabanlı } \\
\text { uygulama }\end{array}$ & $\begin{array}{l}\text {-Doğal yaklaşım } \\
\text {-Bireyselleştirilmiş } \\
\text { bakımın temini } \\
\text {-Otonominin artması } \\
\text {-Özbenlik kullanımının } \\
\text { öneminin artması } \\
\text {-Müşteriler ile ilişkinin } \\
\text { öneminin artması } \\
\text {-Kuruma karşı bağlılık } \\
\text { duygusunun azalması } \\
\text { (Kadının yanında } \\
\text { olma/kadınla birlikte } \\
\text { olma/kadın odaklı } \\
\text { çalışma eğiliminin } \\
\text { artması) }\end{array}$ & 'Kadın ile' & $\begin{array}{l}\text { Çatışmaları çözmek için: } \\
\begin{array}{l}\text { (a) 'kadın ile' ideali ve kurumsal } \\
\text { talepler arasında; } \\
\text { (b) İdealin sürdürülebilirliğine } \\
\text { ilişkin. }\end{array} \\
\text { Hedef='duygusal farkındalık' }\end{array}$ \\
\hline
\end{tabular}

Kaynak: Hunter, B. (2017). Ebelik Mesleğinde Duyguyu Keşfetmek: İlk Ağızdan Açıklama. Rosamund Bryar and Marlene Sinclair (Eds.), Ebelik Uygulamaları İçin Teori içinde (s. 194). Alter Yayıncılık. (Çev. Eds: N. Tuna Oran, H. Öztürk Can).

\section{Ebelikte Duygusal Emek Çalışmalarının Gözden Geçirilmesi}

Hem klinik uygulama hem de duygu çalışmalarında ebelerin özerkliklerinin yüksek olması ve ilişkilerin değerli olduğu durumlarda, duygu çalışması yük yerine fayda sağlayabilmektedir. Ebelikte bakım sürekliliğinin artan iş yükü nedeniyle strese neden olduğuna dair kanıtlar olsa da bunun ebe özerkliğini artırma, karşılıklı değer ve duygusal ödül kaynağı olabileceğinin de tartışıldığı, sorunların bakım sürekliliğinin içeriğinden kaynaklanabileceği belirtilmektedir (Hunter, 2010).

Ebelikte duygu çalışmaları başka araştırmacılar tarafından da ilgi görmüştür. John ve Parsons'ın (2006) doğumhanede çalışan ebelerle yaptıkları çalışmada duygusal emek, ebe tarafından üstlenilen işin görünmeyen bir parçası olarak belirtilmiştir. Çalışmada duygusal emeğin, işi koruma, işe alım sorunları ve yetersiz destek 
mekanizmalarını açıklamada önemli olduğu belirtilmektedir. Ebeler, duygularını duygu yönetimi teknikleri kullanarak kontrol etmekte ve doğal duygular ile profesyonellik gereği hissedilen duygular ebelerde ikilem oluşturmaktadır.

Rayment (2015), ebelerin duygusal emek deneyimlerini incelediği çalışmasında; onların çalışma hayatında başkalarının duyguları ile başa çıkmak için farklı duyguları sergileme sürecinde zorlandığını ve yeterince desteklenemediklerini belirtmektedir. Çalışmada 'Ebelik ideali ile uygulama arasındaki bir çatışma ya da gerginlik, acı çekme ve ölüm gibi durumlarda kadınlarla birlikte olmak, ebelik geribildiriminin işlevsel olmadığ 1 kurumsal sistemler ve zayıf iletişime sahip yöneticiler karşısında ebenin yetersizlik duygusu' şeklinde temel duygu kaynakları belirlenmiştir. Ebeler, kendi duygularıyla kadının doğum deneyimini önemli ölçüde etkilediklerini ve kendilerinin de kadınlardan etkilendiklerini belirtmişlerdir. Ölü doğumla ilk karşılaştığında ağlayan bir deneyimli ebe, sonraları aynı şekilde hissetmesine rağmen duygularını çok fazla göstermediğini, sertleşmek zorunda olduğunu belirtmiştir. Bir başka tecrübeli ebe ise ölü doğum vakalarında keder içinde işini yaptıktan sonra yan odadaki riskli gebenin kendini güvende hissetmesi için gülümsemesi gerektiğinin aşırı derecede rahatsızlık verici olduğunu ve bu duygu geçişlerinin kendilerini zorladığını söylemiştir.

Doğum odalarında çalışan ebelerin, gebelerin memnuniyetini sağlamak için duygusal emek stratejilerini kullanarak duygu çalışması yapmaları gerektiğini belirten Drach-Zavahy ve arkadaşları (2016), ebelerin doğumla ilgili durumlarla karşılaştıklarında duygusal emeğe yönelik öncüllerini ve sonuçlarını incelemek amacıyla bir çalışma yapmışlardır. Bu çalışmada, bir ebe-kadın karşılaşmasında doğum sayısı, epidural analjezi kullanımı, doğum indüksiyonu ve derin veya yüzeysel davranış kullanımını teşvik eden müdahaleli doğum gibi spesifik faktörleri anlamak; duygu çalışmasında kullanılan stratejiler ile doğum deneyimi arasındaki ilişkiyi test etmek; ebenin strateji seçimi arasındaki ilişkilerin olup olmadığını değerlendirmek amaçlanmıştır. Çalışmanın sonucunda, epidural analjezinin yüzeysel davranışlarla negatif ilişkili olduğu; ilk gebeliğe sahip olmanın derinlemesine davranışlar ile anlamlı derecede ilişkili ve yüzeysel davranışlarla negatif ilişkili olduğu; doğum indüksiyonunun derin veya yüzey davranışlarla ilişkili olmadığı; müdahaleli doğumun derinlemesine davranışlarla anlamlı derecede ilişkili ve yüzeysel davranışlarla pozitif ilişkide olduğu bulunmuştur. Ayrıca çalışmada, ebelerin kullandığı yüzeysel davranışların doğum deneyimi ile negatif olarak ilişkiliyken, derinlemesine davranışların pozitif olarak ilişkili olduğu sonucuna varılmıştır. Derinlemesine davranışların özellikle kadın tarafından algılandığında daha etkili olduğu belirtilmekte; mesleki eğitim programlarında duygusal çalışma becerilerine odaklanılması, doğumda kadınlarla nasıl başa çıkılacağının öğretilmesi ve duyguların iyi yönetilmesi gerektiği önerilmektedir.

Fenwick ve arkadaşları (2018), Avustralya ebelerinin duygusal ve profesyonel refahını incelemek amacıyla yaptıkları çalışmalarında; bakımda süreklilik sağlayan ebelerin kaygı, depresyon ve tükenmişlik puanlarının anlamlı derecede düşük olduğu gösterilmektedir. Parçalanmış bakım sağlayan vardiya usulü sistemlerde çalışan ebelerin daha fazla psikolojik sıkıntı riski altında olduğu saptanmıştır.

Leinweber ve arkadaşları (2019), doğum eylemi bakımında ebelerin duygusal emek desteğinin öneminin vurgulandığı çalışmalarında; duygusal uygunluk düzeyinin düşük olduğunu öğrenen ve sonuçları dikkate alan bir ebenin düşünmeye yönelerek neye ihtiyacı olduğunu belirleyebileceği belirtilmektedir.

Ülkemizde, ebelik mesleğini duygusal emek yönünden inceleyen araştırmalar ise; Burdurlu'nun (2017), ebelerin duygusal emek davranışları ve etkileyen faktörlerini incelediği çalışmasında medeni durum, yaş, çalışma şekli, çalışma yllı, iş memnuniyeti ve çocuk sahibi olma gibi faktörlerin doğal duygusal davranış sergilemeyi etkilediği sonucuna varılmıştır. Diğer çalışma da Atasoy ve Turan'ın (2019) ebe ve hemşireler ile yaptıkları çalışmadır. Bu çalışmada duygusal emek ile yaşam doyumları arasındaki ilişki incelenmiştir. Katılımcıların \%32,7'sini ebelerin oluşturduğu çalışmada, duygusal emek ile yaşam doyumları yönünden ebeler ve hemşireler arasında fark bulunamamıştır. Gelirden hoşnut olmanın, işi sevme ve isteyerek seçmenin yaşam doyumunu olumlu etkileyebileceği belirtilmektedir. 
Sağlık çalışanlarında duygusal emeğin tanınması ve işyerindeki duygusal taleplerle başa çıkabilmeleri için desteklenmeleri gerektiği belirtilmektedir (Riley ve Weiss, 2016). Kadına ve aileye yansıması olduğunun bilinmesi bunun gerekliliğini göstermektedir (Hunter, 2010).

\section{Sonuç ve Öneriler}

$\mathrm{Bu}$ derlemede, ebelik mesleğinde duygusal emek gösterimi literatür doğrultusunda incelenmiştir. Ebelikte duygu çalışmaları artmaya başlasa da duygusal emeğin sergilendiği tanımlanmamış birçok alan bulunmaktadır.

Günümüzde hizmet sektörünün önemi giderek artmış, bu durum beraberinde rekabet etme gücünü önemli noktalara taşımıştır. Bu noktadan değerlendirildiğinde sunulan hizmetin kalitesi, hizmetin sunulduğu kesimde yaratılan memnuniyet ve kurumların amaçlarına ulaşabilmeleri için hizmet alanlarla birebir iletişimde olan çalışanların sergilediği duygusal emek önem kazanmıştır.

Ebelik, duygusal emek gerektiren bir meslektir ve çalıştıkları kuruma/alana göre farklı bakış açısı ve ideolojiye sahiptir. Hastanede çalışanlar 'kurum ile' ideolojisini benimserken, sahada çalışanların 'kadın ile' yaklaşımı doğrultusunda görevlerini gerçekleştirdikleri belirlenmiştir.

Ebelerin duygusal emek yükü ile bakım ve uygulamalarda bulunmaları, hizmet alanlarda memnuniyet oluşturabilir. Oluşturulan memnuniyetin artması, sürdürülmesi ve olumlu sonuçların devamlılığının sağlanması için duygusal emek gösterimlerini etkileyen faktörlerin ortaya konması ve hangi sonuçlara yol açtığının izleminin yapılması gerekir. Öte yandan duygusal emeğin kurum, çalışanlar ve hizmet alanlar üzerinde olası olumsuz sonuçları olabilir ve bunların yakından takip edilmesi risklerin saptanmasını ve önceden müdahaleyi mümkün kılabilir. Ebelik mesleğinde duyguların her yönüyle incelenmesi ve tanımlanması uygulamada karşılaşılan duygusal yüklerin azalmasını sağlayabilir. Anne ve çocuk sağlığında önemli olan ebeliğin duygusal yönünün çok yönlü araştırılmasının hem ebeler hem de kadınlar açısından önem taşıdığı düşünülmektedir.

Duygusal emek düzeyi, duygu denetimi, gerekliliği gibi başlıkların motivasyon, tükenmişlik, empati, otonomi, gibi değişkenlerle ilişkisinin inceleceği nitel ve nicel araştırmalara ihtiyaç vardır. Bu nedenle hizmet sektörünün tüm alanlarında duygusal emek kavramının tartışılması, sonuçlarının ortaya konulması ve mezuniyet öncesi eğitimlerde duygusal emek kavramına yer verilmesi önem arz etmektedir. Duygusal emeğin sonuçlarının farkına varılarak ortaya çıkan olumsuz durumlarla baş etmede stratejilerin belirlenmesi hem hizmet sunan hem de yöneticiler için iş gücü kaybını ortadan kaldıracaktır.

\section{Kaynakça}

Atasoy, I. ve Turan, Z. (2019). Ebe ve hemşirelerde duygusal emek ile yaşam doyumu arasındaki ilişkinin incelenmesi. Lokman Hekim Dergisi, 9(3), 357-366. doi: 10.31020/mutftd.587725

Atilla Gök, G. (2015). Merhamet etmenin dayanılmaz ağırlığı: Hemşirelerde merhamet yorgunluğu. SDU* Iktisadi ve Idari Bilimler Fakuiltesi Dergisi, 20(2), 299-313. Erişim adresi: https://dergipark.org.tr/tr/download/article-file/194146

Bolton, S. C., ve Boyd, C. (2003). Trolley Dolly or Skilled Emotion Manager? Moving on from Hochschild's Managed Heart. Work, Employment and Society, 17(2), 289-308. Erişim adresi: https://doi.org/10.1177/0950017003017002004 
Burdurlu, M. (2017). Ebelerde duygusal emek davranışları ve etkili faktörler: Denizli Halk Sağlığı Müdürlüğü Örneği (Yayınlanmamış Yüksek Lisans Tezi). Beykent Üniversitesi, İstanbul.

Çaldağ, M.A. (2010). Duygusal emek davranışlarının sağlık çalışanlarında iş sonuçlarına etkileri (Tez No. 261252) [Yüksek Lisans Tezi, Selçuk Üniversitesi]. Yükseköğretim Kurulu Başkanlığı Tez Merkezi.

Değirmenci Öz, S. ve Baykal, Ü. (2018). Hemşireler için duygusal emek davranışı ölçeğinin geliştirilmesi. Uluslararası Hakemli Hemşirelik Araştırmaları Dergisi, 12, 119-139. doi: 10.17371/UHD.2018.1.3

Delgado, C., Upton, D., Ranse, K., Furness, T. ve Foster, K. (2017). Nurses' resilience and the emotional labour of nursing work: An integrative review of empirical literature. Int J Nurs Stud, 70, 71-88. doi: 10.1016/j.ijnurstu.2017.02.008

Drach-Zavahy, A., Buchnic, R. ve Granot, M. (2016). Antecedents and consequences of emotional work in midwifery: A prospective field study. International Journal of Nursing Studies, 60, 168-178. doi: 10.1016/j.ijnurstu.2016.04.014

Edward, K. L., Hercelinskyj, G. ve Giandinoto, J. A. (2017). Emotional labour in mental health nursing: An integrative systematic review. Int J Ment Health Nurs, 26(3), 215-225. doi: 10.1111/inm.12330

Fenwick, J., Sidebotham, M., Gamble, J. ve Creedy, D. K. (2018). The emotional and professional wellbeing of Australian midwives: A comparison between those providing continuity of midwifery care and those not providing continuity. Women Birth, 31(1), 38-43. doi: 10.1016/j.wombi.2017.06.013

Güngör, M. (2009). Duygusal emek kavramı: Süreci ve sonuçları. Kamu-İş, 11(1), 167-184. Erişim adresi: http://www.kamu-is.org.tr/pdf/1117.pdf

Hunter, B. (2001). Emotion work in midwifery: a review of current knowledge. Journal of Advanced Nursing, 34(4), 436-444. doi: 10.1046/j.1365-2648.2001.01772.x

Hunter, B. (2004). Conflicting ideologies as a source of emotion work in midwifery. Midwifery, 20(3), 261272. doi: 10.1016/j.midw.2003.12.004

Hunter, B. (2005). Emotion work and boundary maintenance in hospital-based midwifery. Midwifery, 21, 253266. doi: $10.1016 /$ j.midw.2004.12.007

Hunter, B. (2006). The importance of reciprocity in relationships between community-based midwives and mothers. Midwifery, 22, 308-322. doi: 10.1016/j.midw.2005.11.002

Hunter, B. (2010). Mapping the emotional terrain of midwifery: What can we see and what lies ahead? Int. J. Work Organisation and Emotion, 3(3), 253-269. doi: 10.1504/IJWOE.2010.032925

Hunter, B. (2017). Ebelik Mesleğinde Duyguyu Keşfetmek: İlk Ağızdan Açılama. Rosamund Bryar and Marlene Sinclair (Eds.), Ebelik Uygulamaları İçin Teori içinde (s. 175-196). Alter Yayıncılık. (Çev. Eds: N. Tuna Oran, H. Öztürk Can).

John, V. ve Parsons, E. (2006). Shadow work in minwifery: unseen and unrecognised emotional labour. British Journal of Midwifery, 14(5), 266-271. doi: 10.12968/bjom.2006.14.5.21046

Kılınç, S. (2018). Sağlık çalışanlarında örgütsel adalet algısının duygusal emek üzerine etkisi: Konya ilinde bir uygulama (Tez No. 508723) [Yüksek Lisans Tezi, Necmettin Erbakan Üniversitesi]. Yükseköğretim Kurulu Başkanlığı Tez Merkezi.

Kirkham, R., Rumbold, A., Hoon, E., Stuart-Butler, D. ve Moore, V. (2018). Emotional labour and aboriginal maternal infant care workers: The invisible load. Women Birth, 31(2), 110-116. doi: 10.1016/j.wombi.2017.07.001 
Leinweber, J., Creedy, D.K., Rowe, H. ve Gamble, J. (2019). Assessing emotional aspects of midwives' intrapartum care: Development of the emotionalavailability and responsiveness in intrapartum care scale. Midwifery, 27(74), 84-90. doi: 10.1016/j.midw.2019.03.019

Mann, S. (2005). A health-care model of emotional labour: An evaluation of the literature and development of a model. Journal of Health Organization and Management, 19(4/5), 304-317. doi: $10.1108 / 14777260510615369$

Oral, L. ve Köse, S. (2011). Hekimlerin duygusal emek kullanımı ile iş doyumu ve tükenmişlik düzeyleri arasındaki ilişkiler üzerine bir araştırma. Süleyman Demirel Üniversitesi İktisadi ve İdari Bilimler Fakültesi Dergisi, 16(2), 463-492. Erişim adresi: https://dergipark.org.tr/tr/download/articlefile/194501

Özbay, O. (2019). Bir kamu hastanesi sağlık çalışanlarında duygusal emek düzeyi ve etkileyen faktörler (Tez No. 587044) [Yüksek Lisans Tezi, Ege Üniversitesi]. Yükseköğretim Kurulu Başkanlığı Tez Merkezi.

Özen, Y. M. (2017). Sağlık çalışanlarında duygusal emek, tükenmişlik ve iş tatmini ilişkisinin incelenmesi: Konya ilinde bir uygulama (Tez No. 471410) [Yüksek Lisans Tezi, Necmettin Erbakan Üniversitesi]. Yükseköğretim Kurulu Başkanlığı Tez Merkezi.

Rayment, J. (2015). Emotional labour: how midwives manage emotion at work. Pract Midwife, 18(3), 9-11. Erişim adresi: https://www.researchgate.net/publication/274408378_Emotional_labour_how_midwives_manage_e motion_at_work

Riley, R. ve Weiss, M. C. (2016). A qualitative thematic review: emotional labour in healthcare settings. $J A d v$ Nurs, 72(1), 6-17. doi: 10.1111/jan.12738

Smith, A. C. ve Kleinman, S. (1989). Managing emotions in medical school: Students' contacts with the living and the dead. Social Psychology Quarterly, 52(1), 56-69. doi: 10.2307/2786904

Tunç, P., Gitmez A. ve Krespi Boothby M.R (2014). Yoğun bakım hemşirelerinin hastalarla ilişkilerinde duygusal emek olarak empati. Anadolu Psikiyatri Dergisi, 15, 45-54. doi: 10.5455/apd.45762

Uzuntarla, Y. (2015). Kişilik özellikleri ile empatik özellikler arasındaki ilişkide duygusal emek ve tükenmişliğin aracılık rolü: Hekimler üzerine bir araştırma (Tez No. 420742) [Doktora Tezi, GATA Sağlık Bilimleri Enstitüsü]. Yükseköğretim Kurulu Başkanlığı Tez Merkezi.

Yetim, B. ve Erigüç, G. (2019). Sağlık çalışanlarında duygusal emek ile ilgili yapılan çalışmalara yönelik bir inceleme. Anadolu Üniversitesi Sosyal Bilimler Dergisi, 19(2), 225-240. Erişim adresi: https://dergipark.org.tr/en/download/article-file/717367

Yılmaz, E. (2016). Dahili kliniklerde çalışan hemşirelerin tükenmişlik düzeyi ve duygusal emek davranışı ile ilişkisi (Tez No. 443647) [Doktora Tezi, Selçuk Üniversitesi] Yükseköğretim Kurulu Başkanlığı Tez Merkezi. 